\title{
METHOD TO DETERMINE THE NUCLIDE INVENTORY OF LOW-ACTIVITY WASTE OF THE RBMK-1500 REACTOR
}

\author{
D. Lukauskas, R. Plukienè, A. Plukis, A. Gudelis, G. Duškesas, L. Juodis, \\ R. Druteikienè, G. Lujanienè, B. Lukšienè, and V. Remeikis \\ Institute of Physics, Savanoriu 231, LT-02300 Vilnius, Lithuania \\ E-mail: vidrem@fi.lt
}

Received 4 October 2006

\begin{abstract}
Results of experimental and modelling evaluation of scaling factors for difficult-to-measure radionuclides in the Ignalina Nuclear Power Plant (INPP) waste are of primary importance in solving the decommissioning problems. The peculiarities of experimental measurements with radiochemical preparation of investigated INPP samples, the analysis of performed alpha, beta, and gamma spectrometric measurements, the theoretical evaluation and estimation of scaling factors, and finally a simplified method of determining the nuclide inventory for very-low-activity waste are presented in this work.
\end{abstract}

Keywords: RBMK radioactive waste, scaling factor, SCALE5 modelling

PACS: 28.41.Kw, 29.30.-h

\section{Introduction}

The radioactive waste management, especially its disposal, is one of the most topical problems in nuclear power engineering. The whole radioactive waste management process is determined by the first step waste characterization. The main requirements for the radioactive waste characterization are accuracy, reliability, expeditiousness, and cheapness. The determination of the concentration of all radiation safety-relevant radionuclides in the radioactive waste can be accurately and reliably performed by applying spectrometry methods in laboratory conditions. But the determination of concentrations of difficult-to-measure longlived gamma emitters in liquid and solid substances, when the analysed isotope is in the complex matrix, requires a complicated and expensive radiochemical extraction procedure. Therefore, such a method cannot be practically applied to the characterization of large amounts of radioactive waste. For this reason, great attention is paid to the development of semi-empirical methods of the radioactive waste nuclide composition determination [1].

Considerable work is done worldwide in applying such methods to the characterization of radioactive waste formed in various types of reactors. The RBMK type reactors are an exception. Despite the fact that these reactors belong to the boiling light water reactor group, they differ from other reactor types by their construction and the used fuel composition (relatively low enrichment, use of burnable Er admixtures), the neutron flux characteristics determining the composition and amounts of formed radionuclides in the spent nuclear fuel (SNF), the activation of reactor construction elements, and also the operational waste composition. Therefore, the activity ratios of various radionuclides determined for the waste of other type reactors cannot be applied to those of the RBMK type reactors.

Two RBMK-1500 type reactors are installed at the Ignalina Nuclear Power Plant (INPP). Decommissioning and dismantling of the Ignalina NPP Unit 1 resulting in approximately 100000 tons of radioactive waste, most of which being of low activity, require immediate development of practically applicable methods of the radioactive waste characterization. At present, verylow-activity Ignalina NPP operational waste (ionizing radiation dose rate at the $10 \mathrm{~cm}$ distance from the surface does not exceed $0.6 \mu \mathrm{Sv} / \mathrm{h}$ ) is accumulated at the special dumping site on the territory of the Ignalina NPP [2]. This dumping site does not have any engineering barriers, and the radioactive waste is dumped straight on the site surface. While managing the Ignalina NPP radioactive waste, the waste was classified according to the gamma radiation intensity at the $10 \mathrm{~cm}$ distance from the surface and according to the surface concentration of alpha and beta emitters. 
Taking into account the radiation safety requirements imposed on the very-low-activity Ignalina NPP operational waste, the list of long-term radiation safetyrelevant radionuclides $\left({ }^{54} \mathrm{Mn},{ }^{55} \mathrm{Fe},{ }^{60} \mathrm{Co},{ }^{65} \mathrm{Zn},{ }^{90} \mathrm{Sr}\right.$, ${ }^{93} \mathrm{Zr},{ }^{93 m} \mathrm{Nb},{ }^{94} \mathrm{Nb},{ }^{110 m} \mathrm{Ag},{ }^{134} \mathrm{Cs},{ }^{137} \mathrm{Cs},{ }^{238} \mathrm{Pu}$, ${ }^{239} \mathrm{Pu},{ }^{240} \mathrm{Pu},{ }^{241} \mathrm{Pu},{ }^{241} \mathrm{Am},{ }^{244} \mathrm{Cm}$ ) was made [3]. The determination of the amount of mentioned radionuclides in the radioactive waste is not a simple task because specific activities of some long-lived radionuclides are low; most of them do not have high energy gamma lines in their decay schemes, in addition, the ionizing radiation (e. g., alpha particles) is strongly absorbed in waste materials and package. Most of transuranic radionuclides belong to such difficult-tomeasure radionuclides, which are alpha emitters, fission products, such as ${ }^{90} \mathrm{Sr}$, which emit only beta particles. Therefore, for the determination of the radionuclide concentration in waste, indirect methods, both semi-empirical and analytical, are developed and used [1]. The radionuclide composition in waste can be determined by applying the scaling factor method using the linear dependence between key radionuclides (e. g., ${ }^{137} \mathrm{Cs},{ }^{60} \mathrm{Co}$ ) and difficult-to-measure ones. This method allows characterizing the waste radiologically by using nondestructive methods. However, the scaling factor method can be applied only when there is a clear correlation between key and difficult-to-measure radionuclides.

In this work a method of determining concentrations of long-term radiation safety-relevant radionuclides in the Ignalina NPP very-low-activity operational waste according to the activity of the easy-to-measure gamma emitter ${ }^{60} \mathrm{Co}$ is presented. The method is based not only on the experimental measurements of various radionuclides but in some cases on the computer modelling results of nuclear fuel composition and the reactor construction material activation in the reactor neutron flux.

\section{Methods}

The scaling factor method is widely used in characterizing the radioactive waste [1]. It is based on the empirical dependence between specific activities of nuclides in the investigated sample when the main pollution source is the same, e. g., the nuclear reactors:

$$
A_{i} \propto A_{\mathrm{key}}
$$

where $A_{i}$ is the specific activity of the difficult-tomeasure radionuclide, $A_{\mathrm{key}}$ is the specific activity of the easy-to-measure key radionuclide.
Table 1 . The list of experimentally measured radionuclides in the operational waste of INPP.

\begin{tabular}{cc}
\hline Radiation & Radionuclides \\
\hline$\gamma$ & ${ }^{54} \mathbf{M n},{ }^{58} \mathrm{Co},{ }^{60} \mathbf{C o},{ }^{59} \mathrm{Fe},{ }^{51} \mathrm{Cr},{ }^{65} \mathbf{Z n}$, \\
& ${ }^{94} \mathbf{N b},{ }^{95} \mathrm{Zr},{ }^{95} \mathrm{Nb},{ }^{110 m} \mathbf{A g},{ }^{131} \mathrm{I},{ }^{140} \mathrm{Ba}$, \\
& ${ }^{140} \mathrm{La},{ }^{134} \mathbf{C s},{ }^{137} \mathbf{C s},{ }^{166 m} \mathrm{Ho},{ }^{181} \mathrm{Hf}$ \\
\hline$\gamma^{*}$ & ${ }^{130} \mathrm{I},{ }^{132} \mathrm{I},{ }^{133} \mathrm{I},{ }^{134} \mathrm{I},{ }^{135} \mathrm{I},{ }^{41} \mathrm{Ar},{ }^{133} \mathrm{Xe}$, \\
& ${ }^{135} \mathrm{Xe},{ }^{138} \mathrm{Cs},{ }^{239} \mathrm{~Np},{ }^{101} \mathrm{Tc},{ }^{104} \mathrm{Tc},{ }^{99} \mathrm{Mo}$, \\
& ${ }^{56} \mathrm{Mn},{ }^{187} \mathrm{~W},{ }^{87} \mathrm{Kr},{ }^{88} \mathrm{Kr},{ }^{82} \mathrm{Br},{ }^{93} \mathrm{Sr}$ \\
\hline$\beta$ & ${ }^{3} \mathrm{H},{ }^{14} \mathrm{C},{ }^{55} \mathbf{F e},{ }^{63} \mathrm{Ni},{ }^{90} \mathrm{Sr},{ }^{241} \mathbf{P u}$ \\
\hline$\alpha$ & ${ }^{238} \mathbf{P u},{ }^{239+240} \mathbf{P u},{ }^{241} \mathbf{A m},{ }^{242} \mathrm{Cm},{ }^{243+244} \mathbf{C m}$ \\
\hline
\end{tabular}

* Additionally registered radionuclides by measuring the coolant samples with the portable gamma spectrometer immediately after their sampling.

The most frequently used linear dependence between these quantities is

$$
A_{i}=k_{i} \cdot A_{\mathrm{key}},
$$

where $k_{i}$ is a constant, called the scaling factor.

The most accurate approach to determine the scaling factors is a direct measurement of activities of all investigated radionuclides in samples. The scaling factors of radionuclides, the specific activity of which can be measured by $\alpha, \beta$, and $\gamma$ spectrometric methods, are determined by the measurement runs, statistically processing the results according to the correlation of the investigated radionuclide with the key nuclides. To ensure that results are reliable, the sample should meet the Grubb's test and the measured specific activities should cover the whole possible interval. In this case, the upper and lower boundaries of the scaling factor are directly obtained from the correlation function reliability interval. The nuclide activity measurement method will be provided below.

Radionuclides, the specific activities of which can be measured by the alpha, beta, and gamma spectrometric methods, are presented in Table 1. Radionuclides from the list of radiation safety-relevant ones are shown in bold.

As mentioned before, huge amounts of very-lowactivity (surface dose $>0.6 \mu \mathrm{Sv} / \mathrm{h}$ ) operational waste of the Ignalina NPP are accumulated. This radioactive operational waste includes variety of materials: concrete, plaster, metal construction components, cotton and synthetic fabrics, plastic floor fragments, polythene, timber, etc. The representative samples of all these materials were taken at special waste storage places at the Ignalina NPP industrial site. Each sample was tested with the dosimeter and placed into the polythene closing bag, by writing down the sample code 


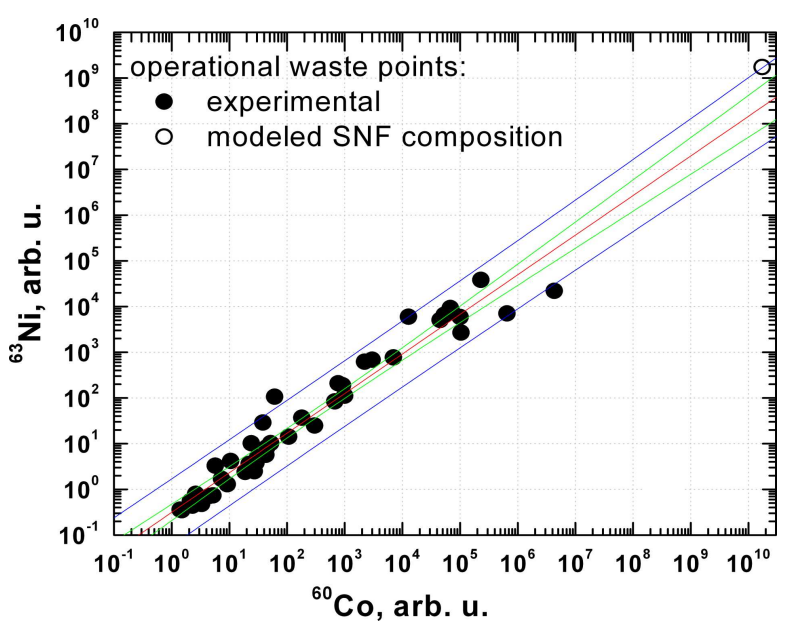

(a)

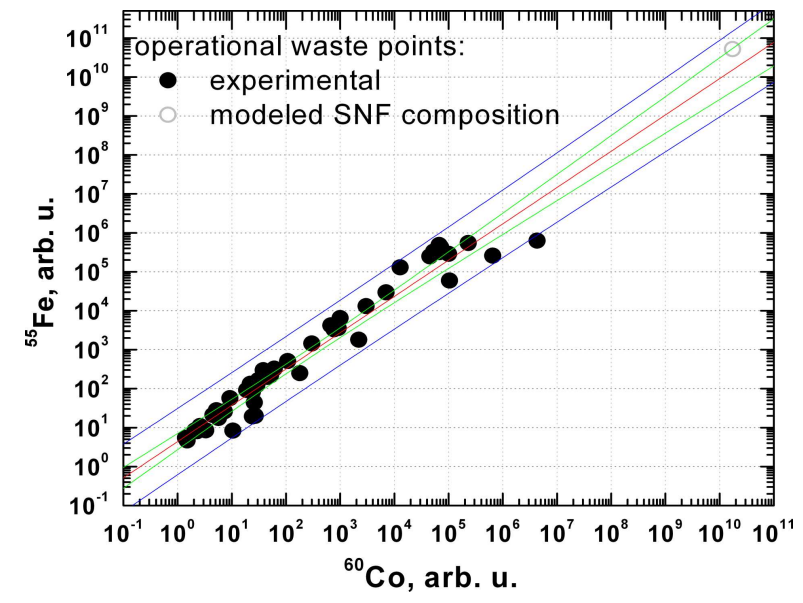

(b)

Fig. 1. Correlations between measured specific activities of (a) ${ }^{63} \mathrm{Ni}$ versus ${ }^{60} \mathrm{Co}$, (b) ${ }^{55} \mathrm{Fe}$ versus ${ }^{60} \mathrm{Co}$ in radioactive waste.

indicating the sampling place and time. Such marked bags with samples were put into a large polyethylene bag intended for the sample transportation to the laboratory. Forty nine samples were taken in total.

Water samples from the reactor main circulation circuit were taken from special taps by pouring a needed amount of water (usually $500 \mathrm{ml}$ ) into the polythene container. After sampling the water was acidified with $12 \mathrm{~mol} / 1$ hydrochloric acid solution to the $\mathrm{pH}$ value of 2. Ten samples were taken in all.

Both qualitative and quantitative gamma spectrometry was applied using two gamma-ray spectrometers, stationary and portable, with high purity germanium (HPGe) semiconductor detectors. The stationary spectrometer comprised two Ge detectors, with relative efficiencies of $38 \%$ and $30 \%$ and the respective energy resolution $2.05 \mathrm{keV}$ and $1.80 \mathrm{keV}$ at $1333 \mathrm{keV}$. This spectrometer ensures the measurement of absolute activity of all radionuclides in the $122-1461 \mathrm{keV}$ energy range with the uncertainty not exceeding $6 \%$
[4]. The coincidence-summing corrections were applied when measuring activities of radionuclides whose decay schemes incorporated the cascade transitions $\left({ }^{60} \mathrm{Co},{ }^{94} \mathrm{Nb},{ }^{134} \mathrm{Cs}\right)$. The counting efficiency was also corrected for the sample aliquot density; the final result was decay-corrected to the sampling date. The activity of short-lived radionuclides originated in water of the main circulation circuit was measured with the portable spectrometer immediately after the coolant sampling. The activity of these radionuclides was determined with the uncertainty not larger than $30 \%$. The relative efficiency of the portable detector was $20 \%$ while the energy resolution was $1.80 \mathrm{keV}$ at $1333 \mathrm{keV}$. Using this spectrometer the in situ measurements were also carried out in the Ignalina NPP industrial site sectors where operational waste is accumulated and sorted.

Radiochemical separation methods are applied to the activity determination of beta and alpha emitters. In order to maintain the sample homogeneity and to reduce the labour expenditure, radiochemical procedures of separating the radionuclides were performed for the radionuclide complex determination from one sample. For this purpose, the method allowing extraction and qualitative determination of ${ }^{55} \mathrm{Fe}$ and ${ }^{90} \mathrm{Sr}$ was developed. ${ }^{55} \mathrm{Fe}$ and ${ }^{90} \mathrm{Sr}$ analysis was carried out by the extraction chromatography method $[5,6]$. Before the procedure, the concentration of chemical elements in the sample was determined with the atomic absorption spectrophotometer. For the chemical yield determination, stable $\mathrm{Fe}^{3+}$ and $\mathrm{Sr}^{2+}$ carriers were introduced into the test portion. The amount of the test portion was determined according to the specific activities of ${ }^{137} \mathrm{Cs}$ and ${ }^{60} \mathrm{Co}$ by performing the gamma spectrometric analysis. The $\mathrm{Pu}$ isotopes from solid waste were extracted using the ion exchange chromatography method [7-11], and from liquid waste by the extraction chromatography method.

${ }^{55} \mathrm{Fe},{ }^{90} \mathrm{Sr}$, and ${ }^{241} \mathrm{Pu}$ were measured with the liquid scintillation beta spectrometer Quantulus-1220. For the measurement of ${ }^{241} \mathrm{Pu}$, scintillation solutions were prepared from the material obtained after washing the electrolysis disc prepared for alpha spectrometry and the scintillator OptiPhase HiSafe 2. The measurement uncertainty was not higher than $10 \%$. The radionuclide detection limits (with the measurement duration of $180 \mathrm{~min}$.) for ${ }^{55} \mathrm{Fe}$ were $110 \mathrm{~Bq} / \mathrm{kg}$, for ${ }^{90} \mathrm{Sr} 73 \mathrm{~Bq} / \mathrm{kg}$, for ${ }^{241} \mathrm{Pu} 7.2 \mathrm{~Bq} / \mathrm{kg}$. Here the specific activity detection limit is indicated assuming that the element radiochemical extraction yield is $50 \%$, and $0.6 \mathrm{~g}$ samples containing ${ }^{55} \mathrm{Fe}$ and ${ }^{90} \mathrm{Sr}$ and $5 \mathrm{~g}$ sample containing ${ }^{241} \mathrm{Pu}$ were taken for analysis. The 


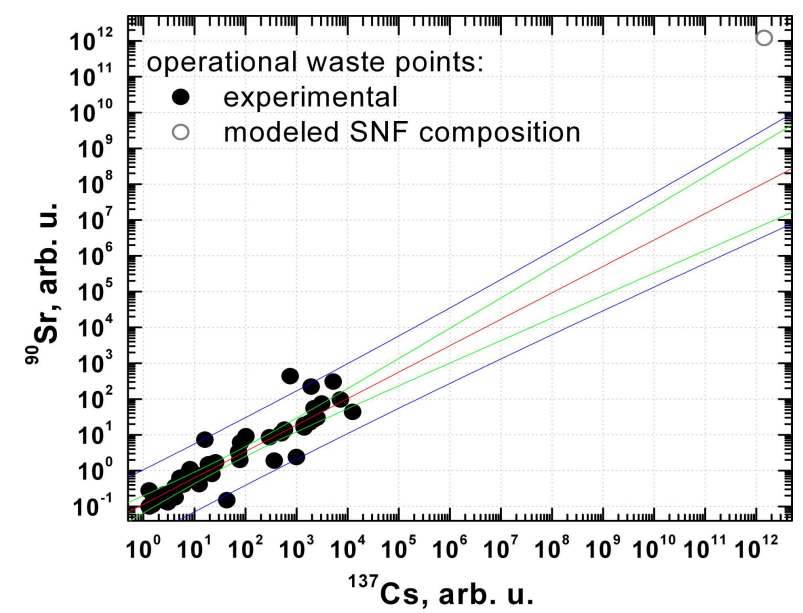

Fig. 2. Correlation between measured ${ }^{90} \mathrm{Sr}$ and ${ }^{137} \mathrm{Cs}$ specific activities in radioactive waste.

activity of ${ }^{238} \mathrm{Pu},{ }^{239+240} \mathrm{Pu},{ }^{241} \mathrm{Am},{ }^{243+244} \mathrm{Cm}$ was determined with the alpha spectrometer, the detection limit at the measurement duration of $100000 \mathrm{~s}$ being $0.001 \mathrm{~Bq}$. This corresponds to the specific activity of $0.4 \mathrm{~Bq} / \mathrm{kg}$ at the $22 \%$ measurement uncertainty. The chemical yield of the analytical procedure changes from 70 to $90 \%$ for $\mathrm{Pu}$, from 60 to $80 \%$ for $\mathrm{Am}$. The minimal detection limit for $\mathrm{Pu}$ is $0.001 \mathrm{~Bq} /$ sample, for $\mathrm{Am}$ it is $0.0015 \mathrm{~Bq} /$ sample.

When the radionuclide specific activity in radioactive waste is lower than the detection limit of the available measurement device, the specific activity of this radionuclide can be evaluated only by computational modelling. Modelling can also be used in the cases when it is complicated and expensive to make measurements.

The indirect methods were used for radionuclides, whose activity measurement is difficult or even impossible. As the main source of the nuclide origin in waste is the nuclear reactor, so the nuclide formation in the nuclear fuel and construction materials was simulated. Modelling was performed by applying the program package SCALE $5[12,13]$. The nuclide transfer from the nuclear fuel was evaluated by measuring activities in possible transfer media (main circulation circuit coolant, spent nuclear fuel storage basin water, etc.). When calculating the correlation dependence, it was taken into account whether the scaling factors between the radionuclide transfer in media differed significantly from the nuclide ratios in the nuclear fuel. If the difference was larger than two orders of magnitude, the additional key nuclides, whose calculated activities in nuclear fuel and the main circulation circuit coolant

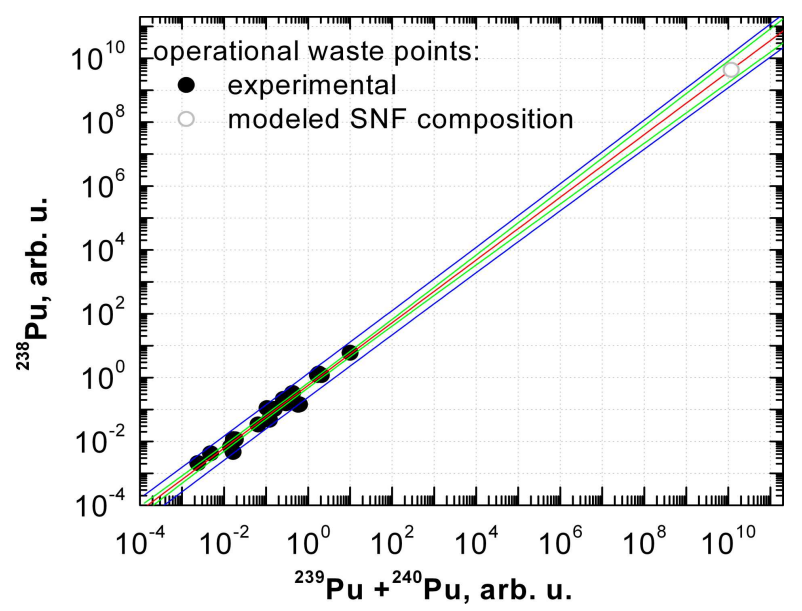

Fig. 3. Correlation between measured specific activities of ${ }^{238} \mathrm{Pu}$ and sum of ${ }^{239} \mathrm{Pu}$ and ${ }^{240} \mathrm{Pu}$ in radioactive waste.

or in radioactive waste correlated better, were selected. Then the scaling factor was calculated by an equation

$$
k_{i}=k_{i j} \cdot k_{j},
$$

where $k_{i}$ is the scaling factor of the investigated radionuclide, $k_{i j}$ is the scaling factor of the investigated radionuclide in respect of the intermediate key radionuclide, $k_{j}$ is the scaling factor of the intermediate radionuclide.

The scaling factors of nuclides which are practically very difficult-to-measure, e. g., ${ }^{240} \mathrm{Pu}$, were estimated according to the modelling ratio to the intermediate radionuclide, the scaling factors of which were measured directly.

It is not possible to measure specific activities of ${ }^{93 m} \mathrm{Nb}$ and ${ }^{93} \mathrm{Zr}$ in the radioactive operational waste of the Ignalina NPP due to large expenditures. Specific activities of these radionuclides can be evaluated by computational modelling if the theoretical activity ratio of ${ }^{93} \mathrm{Zr}$ and ${ }^{95} \mathrm{Zr}$ or ${ }^{93} \mathrm{Zr}$ and ${ }^{94} \mathrm{Nb},{ }^{93 m} \mathrm{Nb}$ and ${ }^{94} \mathrm{Nb}$ activity ratio is known.

It is difficult to measure the activity of individual isotopes of ${ }^{239} \mathrm{Pu},{ }^{240} \mathrm{Pu},{ }^{243} \mathrm{Cm}$, and ${ }^{244} \mathrm{Cm}$ because peaks of ${ }^{239} \mathrm{Pu}$ and ${ }^{240} \mathrm{Pu}$ as well as of ${ }^{243} \mathrm{Cm}$ and ${ }^{244} \mathrm{Cm}$ cannot be distinguished by the alpha spectrometry, and only the total activity of two plutonium isotopes or two curium isotopes is measured. In this case the modelled activity ratio of ${ }^{239} \mathrm{Pu}$ and ${ }^{240} \mathrm{Pu}$ as well as of ${ }^{243} \mathrm{Cm}$ and ${ }^{244} \mathrm{Cm}$ is used for the determination of the individual radionuclide activity taking into account their measured total activity. 
Table 2. The scaling factors of INPP very-low-activity operational waste according to key nuclide ${ }^{60}$ Co activity.

\begin{tabular}{ccccc}
\hline Nuclide & Scaling factor $k_{60_{\mathrm{Co}}}$ & Lower boundary & Upper boundary & Correlation coefficient $^{*}$ \\
\hline${ }^{54} \mathrm{Mn}$ & 0.30 & 0.07 & 1.19 & 0.95 \\
${ }^{55} \mathrm{Fe}$ & 2.89 & 1.20 & 6.99 & 0.97 \\
${ }^{65} \mathrm{Zn}$ & 0.012 & $2.73 \cdot 10^{-3}$ & $2.08 \cdot 10^{-2}$ & 0.94 \\
${ }^{90} \mathrm{Sr}$ & $7.57 \cdot 10^{-3}$ & $2.35 \cdot 10^{-3}$ & $2.08 \cdot 10^{-2}$ & 0.89 \\
${ }^{93} \mathrm{Zr}$ & $1.00 \cdot 10^{-4}$ & $4.38 \cdot 10^{-6}$ & $2.35 \cdot 10^{-3}$ & \\
${ }^{93 m} \mathrm{Nb}$ & 0.13 & $5.7 \cdot 10^{-3}$ & 3.06 & \\
${ }^{94} \mathrm{Nb}$ & 0.01 & $4.38 \cdot 10^{-4}$ & 0.24 & \\
${ }^{110 m} \mathrm{Ag}$ & $3.34 \cdot 10^{-2}$ & $1.09 \cdot 10^{-3}$ & 1.03 & \\
${ }^{134} \mathrm{Cs}$ & 0.05 & $1.57 \cdot 10^{-3}$ & 1.61 & \\
${ }^{137} \mathrm{Cs}$ & 0.16 & 0.05 & 0.46 & \\
${ }^{238} \mathrm{Pu}$ & $6.57 \cdot 10^{-5}$ & $8.05 \cdot 10^{-6}$ & $5.37 \cdot 10^{-4}$ & \\
${ }^{239} \mathrm{Pu}$ & $4.94 \cdot 10^{-5}$ & $6.04 \cdot 10^{-6}$ & $4.04 \cdot 10^{-4}$ & \\
${ }^{240} \mathrm{Pu}$ & $6.21 \cdot 10^{-5}$ & $7.61 \cdot 10^{-6}$ & $5.07 \cdot 10^{-4}$ & \\
${ }^{241} \mathrm{Pu}$ & 0.013 & 0.002 & 0.11 & \\
${ }^{241} \mathrm{Am}$ & $1.37 \cdot 10^{-4}$ & $1.68 \cdot 10^{-5}$ & $1.12 \cdot 10^{-3}$ & \\
${ }^{244} \mathrm{Cm}$ & $1.99 \cdot 10^{-4}$ & $2.43 \cdot 10^{-5}$ & $1.62 \cdot 10^{-3}$ & \\
\hline
\end{tabular}

${ }^{*}$ The correlation coefficient is presented only in the cases when there are enough experimental data for its determination.

\section{Results}

The common practice is that the activity control of solid radioactive waste to be stored at the operational waste site is performed by measuring the total $\gamma$-radiation intensity. Therefore, it is convenient to select ${ }^{60} \mathrm{Co}$ as a key nuclide because according to the measurements its contribution to the total gamma radiation intensity is the largest due to its high concentration in the radioactive waste. High energy gamma rays $(1.16 \mathrm{MeV}$ and $1.33 \mathrm{MeV})$ of ${ }^{60} \mathrm{Co}$ are weakly absorbed in the waste media and that is the reason why it dominates the total gamma radiation.

The specific activities of measured ${ }^{63} \mathrm{Ni}$ and ${ }^{55} \mathrm{Fe}$ versus ${ }^{60} \mathrm{Co}$ specific activities in very-low-activity radioactive waste from the INPP are presented in Fig. 1. The calculated activities of nuclides in RBMK-1500 reactor fuel assemblies are also shown. These data clearly show the linear dependence function between specific activities when data are presented on a logarithmic scale. Linear function $\lg \left(A_{i}\right)=\lg \left(k_{i}\right)+q$. $\lg \left(A_{\text {key }}\right)$ can be used for fitting of data, where $q$ is the line slope and other terms are described in Eqs. (1) and (2). When a fit is good enough, as presented in Fig. $1(\mathrm{a}, \mathrm{b}), q$ is close to unity and the fit function is identical to that in Eq. (2). From confidence bands it is possible to obtain uncertainty of the scaling factor and from the upper prediction band one can find the upper limit of nuclide activity in the radioactive waste when the key nuclide activity is known.

For some nuclides there was no good correlation between their activities and those of the single key nu-

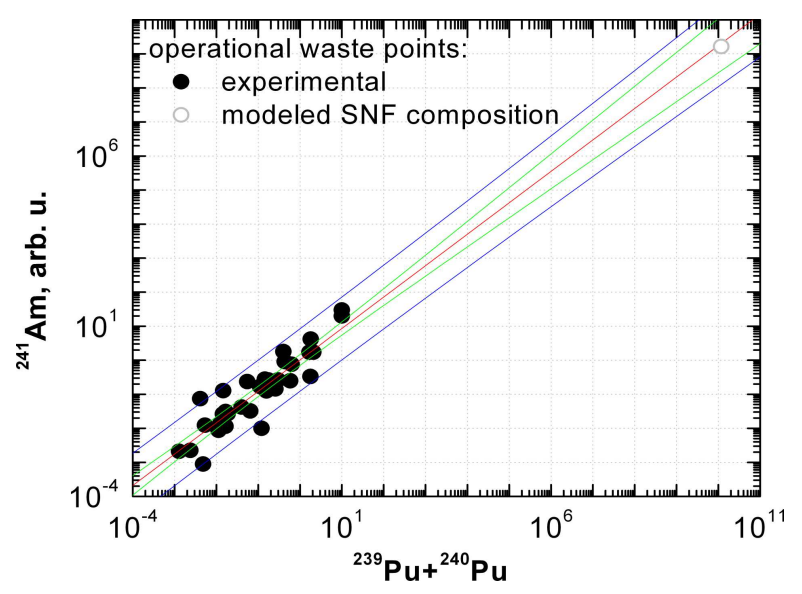

Fig. 4. Correlation between measured specific activities of ${ }^{241} \mathrm{Am}$ and sum of ${ }^{239} \mathrm{Pu}$ and ${ }^{240} \mathrm{Pu}$ in radioactive waste.

clide. Then the correlation with intermediate nuclides as presented in previous section was used. Examples of using ${ }^{137} \mathrm{Cs}$ and a sum of ${ }^{239} \mathrm{Pu}$ and ${ }^{240} \mathrm{Pu}$ activities as intermediate key nuclides are presented in Figs. 24. One can notice that calculated activities of ${ }^{90} \mathrm{Sr}$ and ${ }^{137} \mathrm{Cs}$ in spent nuclear fuel do not follow the trend of experimentally measured activities in the radioactive waste. This is caused by different release rates of Cs and $\mathrm{Sr}$ from the nuclear fuel matrix to the main circulation circuit of the reactor. In this case calculated data points are excluded from the fit.

The scaling factors determined by the described method are presented in Table 2. The scaling factors for radionuclides were calculated so that they approximate the functional dependence of the nuclide activities without damaging the conservative evaluation principle. The scaling factors between activities of the key 
nuclide ${ }^{60} \mathrm{Co}$ and other nuclides $-{ }^{54} \mathrm{Mn},{ }^{55} \mathrm{Fe},{ }^{65} \mathrm{Zn}$, ${ }^{94} \mathrm{Nb},{ }^{137} \mathrm{Cs}$ - were determined from the direct experimental measurements. The correlation coefficient between specific activities of those nuclides and ${ }^{60} \mathrm{Co}$ was larger than 0.9 as presented in Table 2. Due to better correlation, ${ }^{137} \mathrm{Cs}$ was selected as a suitable intermediate key nuclide for the determination of scaling factors of ${ }^{90} \mathrm{Sr}$ and ${ }^{134} \mathrm{Cs}$ nuclide activities and afterwards the corresponding scaling factor for these nuclides and ${ }^{60} \mathrm{Co}$ was recalculated. The scaling factors of actinide activities were estimated by applying the correlation with the sum activity of ${ }^{239} \mathrm{Pu}+{ }^{240} \mathrm{Pu}$ measured by alpha spectrometry as intermediate key nuclides. The scaling factors of ${ }^{93 m} \mathrm{Nb}$ and ${ }^{93} \mathrm{Zr}$ were evaluated from modelling results of the activity ratio of ${ }^{93} \mathrm{Zr}$ and ${ }^{95} \mathrm{Zr}$ or ${ }^{93} \mathrm{Zr}$ and ${ }^{94} \mathrm{Nb},{ }^{93 m} \mathrm{Nb}$, and ${ }^{94} \mathrm{Nb}$ taking into account the ratios of modelled and experimentally obtained radionuclides. The scaling factor of ${ }^{110 m} \mathrm{Ag}$ with ${ }^{60} \mathrm{Co}$ was also obtained by combining modelling ratio results and correlation with the intermediate key nuclide ${ }^{137} \mathrm{Cs}$, as both of them belong to fission products. The lower and upper boundaries indicate the limits of the scaling factor application to each nuclide considered. One can notice that these limits are broad enough in order to guarantee its applicability to a variety of verylow-activity samples.

\section{Conclusions}

- The method of scaling factors was implemented. It properly characterizes the composition of the radioactive waste accumulated during the RBMK1500 reactor operation.

- ${ }^{60} \mathrm{Co}$ was chosen as the key nuclide for very-lowactivity waste characterization due to simplicity of its experimental analysis.

- The scaling factors between activities of the key nuclide ${ }^{60} \mathrm{Co}$ and other nuclides $-{ }^{54} \mathrm{Mn},{ }^{55} \mathrm{Fe},{ }^{65} \mathrm{Zn}$, ${ }^{94} \mathrm{Nb},{ }^{137} \mathrm{Cs}$ - were determined from the direct experimental measurements. The correlation coefficient between specific activities of these nuclides and ${ }^{60} \mathrm{Co}$ was larger than 0.9 .

- ${ }^{137} \mathrm{Cs}$ was selected as a suitable intermediate key nuclide for the determination of the scaling factors of ${ }^{90} \mathrm{Sr}$ and ${ }^{134} \mathrm{Cs}$ nuclide activities.

- The scaling factors of actinide activities were estimated by applying the correlation with the sum activity of ${ }^{239} \mathrm{Pu}+{ }^{240} \mathrm{Pu}$ as intermediate key nuclides.

\section{Acknowledgement}

This study was supported by the Lithuanian State Science and Studies Foundation in the frame of Project No. G-81 / 06.

\section{References}

[1] W. Müller, Activity determination and declaration an overview, in: Determination and Declaration of Nuclide Specific Actvity Inventories in Radioactive Wastes, International workshop (Cologne, Germany, 2001).

[2] R.E. Wright, N. Fletcher, R.D. Pearsall, V.E. Sidnev, J.H. Bickel, and A. Vianello, Upgrade of control and protection system of the Ignalina Nuclear Power Plant units 1 and 2, Nucl. Technol. 143(2), 241-245 (2003).

[3] V. Remeikis, D. Lukauskas, D. Baltrūnas, A. Plukis, G. Duškesas, R. Druteikienè, B. Lukšienè, G. Lujaniené, and A. Gudelis, Methods of determining safety-relevant radionuclides in the nuclear power plant radioactive waste, Environmental Chem. Phys. 26(4), 157-163 (2004).

[4] A. Gudelis, V. Remeikis, A. Plukis, and D. Lukauskas, Efficiency calibration of HPGe detectors for measuring environmental samples, Environmental Chem. Phys. 22(3-4), 117-125 (2000).

[5] P.E. Warwick and I.W. Croundance, Separation of iron-55/59 from fission and activation products using Diisobutylketone-based extraction chromatographic materials, in: Environmental Radiochemical Analysis II, ed. P. Warwick (Royal Society of Chemistry, Southampton, 2002), $417 \mathrm{p}$.

[6] C. Testa, D. Desideri. M.A. Meli, and C. Roselli, Extraction chromatography in radioecology, Radioactivity Radiochem. 2(4), 46-55 (1991).

[7] K. Bunzl and W. Kracke, Simultaneous determination of ${ }^{238} \mathrm{Pu},{ }^{239,240} \mathrm{Pu},{ }^{241} \mathrm{Pu},{ }^{241} \mathrm{Am},{ }^{242} \mathrm{Cm},{ }^{244} \mathrm{Cm}$, ${ }^{89} \mathrm{Sr}$ and ${ }^{90} \mathrm{Sr}$ in vegetation samples and application to Chernobyl-fallout contaminated grass, J. Radioanal. Nucl. Chem. 138(1), 83-91 (1990).

[8] E.P. Horwitz, M.T. Dietz, and D.E. Fisher, Extraction of strontium from nitric acid solutions using dicyclohexano-18-crown-6 and its derivatives, Solvent Extraction Ion Exchange 8(4), 557-572 (1990).

[9] E.P. Horwitz, R. Chiarizia, M.L. Dietz, H. Diamond, and D.M. Nelson, Separation and preconcentration of actinides from acidic media by extraction chromatography, Analytica Chimica Acta 281(2), 361-372 (1993).

[10] R. Pilvio, M. Bickel, G. Van Britson, and B. Slowikowski, New developments in the separation and detection of actinides in water samples, in: Proceedings of International Seminar on the Use of Isotope Techniques in Marine Environmental Studies (Vienna, Austria, 1998). 
[11] Q. Chen, A. Aarkrog, S.P. Nielsen, H. Dahlgaard, B. Lind, A.K. Kolstad, and Y. Yu, Procedures for Determination of ${ }^{239,240} \mathrm{Pu},{ }^{241} \mathrm{Am},{ }^{237} \mathrm{~Np},{ }^{234,238} \mathrm{U}$, ${ }^{228,230,232} \mathrm{Th},{ }^{99} \mathrm{Tc}$ and ${ }^{210} \mathrm{~Pb}-{ }^{210} \mathrm{Po}$ in Environmental Materials (Risø National Laboratory, Roskilde, 2001).

[12] S.M. Bowman, D.F. Hollenbach, M.D. DeHart et al., SCALE 5: Powerful new criticality safety analysis tools, in: Proceedings of the 7th International Confer- ence on Nuclear Criticality Safety (ICNC2003) (Tokaimura, Japan, 2003).

[13] V. Remeikis, G. Klevinskas, L. Juodis, A. Plukis, and R. Plukienè, Analysis of the relative release rate of radionuclides from the RBMK-1500 reactor fuel elements, Nucl. Eng. Design (2006) [in press, available online at wWw. sciencedirect.com].

\title{
NUKLIDINĖS SUDĖTIES RBMK-1500 REAKTORIAUS MAŽO RADIOAKTYVUMO ATLIEKOSE NUSTATYMO METODAS
}

\author{
D. Lukauskas, R. Plukienè, A. Plukis, A. Gudelis, G. Duškesas, L. Juodis, R. Druteikienė, G. Lujanienė, \\ B. Lukšienè, V. Remeikis
}

Fizikos institutas, Vilnius, Lietuva

\begin{abstract}
Santrauka
Vienas iš aktualiausių uždavinių atominèje energetikoje yra radioaktyviujju atliekų tvarkymas, ypač jų laidojimas. Visą radioaktyviųų atliekų tvarkymo procesą lemia pirmasis žingsnis - radioaktyviųjų atliekų apibūdinimas. Pagrindiniai reikalavimai, keliami radioaktyviųuu atliekų apibūdinimui, yra tikslumas, patikimumas, operatyvumas bei vertinimo būdo ekonomiškumas. Sunkumai iškyla, kai susiduriama su mažos energijos ilgaamžiais gama bei alfa ar beta spinduoliais, kurių koncentracijų nustatymas yra ilgai trunkantis bei sudetingas, todèl radioaktyviosioms atliekoms charakterizuoti pasirenkami pusiauempiriniai - radionuklidu aktyvumo proporcingumo daugikliais paremti - metodai, kai atlieku nuklidinei sudéčiai identifikuoti pasitelkiami kompiuterinio modeliavimo bei išsamūs radiocheminiai, branduolinès ir masių spektrometrijos metodai ir pateikiamas proporcingumo daugiklių, apibrěžiančių aktyvumo santyki tarp vieno ar kelių atraminių ir ieškomo nuklido aktyvumų, rinkinys. Yra nemažai nuveikta, taikant tokius metodus įvairių tipų reaktoriuose susidarančioms radioakty-
\end{abstract}

viosioms atliekoms apibūdinti, tačiau RBMK reaktorių eksploatacinių atliekų apibūdinimui, dèl jų konstrukcijos, naudojamo kuro sudèties, neutronų srauto parametrų bei eksploatavimo ypatybių, pasauline patirtimi negalima vienareikšmiškai pasinaudoti.

Šiame darbe išvystytas pusiauempirinis metodas radionuklidų aktyvumo proporcingumo daugikliams Ignalinos AE eksploatacinèse atliekose nustatyti. Visiems eksploatacinių radioaktyviuju atlieku srautams tikslinga naudoti vienodą radionuklidų aktyvumo proporcingumo daugiklių rinkini. Nustatyta, kad eksploatacinėms atliekoms apibūdinti, dèl eksperimentinès analizès paprastumo, geriausiai tinka ${ }^{60} \mathrm{Co}$. Daugeliui radiacinès saugos požiūriu svarbiu radionuklidu $\left({ }^{54} \mathrm{Mn},{ }^{55} \mathrm{Fe},{ }^{65} \mathrm{Zn},{ }^{94} \mathrm{Nb},{ }^{137} \mathrm{Cs}\right)$ aktyvumo proporcingumo daugiklis buvo surastas iš tiesioginių eksperimentinių matavimų, koreliacijos koeficientas su ${ }^{60} \mathrm{Co}$ viršija $0,9 .{ }^{90} \mathrm{Sr}$ ir ${ }^{134} \mathrm{Cs}$ aktyvumo proporcingumo daugikliai buvo nustatyti per tarpinio atraminio nuklido ${ }^{137} \mathrm{Cs}$ vertes. Aktinoidu aktyvumo proporcingumo daugikliai nustatyti per tarpines alfa spektrometriškai išmatuotas suminio ${ }^{239} \mathrm{Pu}+{ }^{240} \mathrm{Pu}$ aktyvumo vertes. 